\title{
PEMAHAMAN LITERASI MEDIA DI LINGKUNGAN PENGURUS PIMPINAN WILAYAH AISYIYAH DAERAH ISTIMEWA YOGYAKARTA \\ PERIODE 2015-2020
}

\author{
Mariana Ulfah, Choirul Fajri, dan Dani Fadillah \\ mj.mariajova@gmail.com, choirul.fajri@comm.uad.ac.id,daniuad@yahoo.co.id \\ Program Studi Ilmu Komunikasi \\ Fakultas Sastra, Budaya, dan Komunikasi \\ Universitas Ahmad Dahlan
}

\begin{abstract}
As parents mothers play an important role in giving directions to targeted all relating to the event who deserves to consume by family. This study was conducted by adopting descriptive quantitative. Handing out the questionnaire to the Leader of 'Aisyiyah DIY the period 2015-2020. The result of shows that there has been understanding of literacy media of 'Aisyiyah DIY, the attitude shown to the son of/his daughter in preventing negative effects impressions television. But of the that good, do not affect significantly to the attitudes shown.
\end{abstract}

\begin{abstract}
Abstrak
Sebagai orang tua Ibu memiliki peran penting dalam memberikan arahan kepada putra-putrinya terkait dengan acara yang layak untuk dikonsumsi keluarga. Penelitian ini dilaksanakan dengan menggunakan pendekatan deskriptif kuantitatif. Dengan membagikan kuesioner kepada Pengurus Pimpinan Wilayah Aisyiyah Yogyakarta periode 2015-2020. Hasil dari menunjukkan adanya pemahaman dari literasi media Pengurus PWA 'Aisyiyah DIY, adanya sikap yang ditunjukkan kepada putra/putrinya dalam mencegah dampak buruk tayangan televisi. Akan tetapi dari pemahaman yang baik tersebut, tidak berpengaruh secara signifikan terhadap sikap yang ditunjukkan.
\end{abstract}

Keywords: Literacy, Mass Media, 'Aisyiyah

\section{PENDAHULUAN}

Televisi sudah bukan lagi menjadi barang mewah seperti saat-saat awal kemunculannya, saat ini televisi telah menjadi barang yang senantiasa ada di setiap rumah keluarga Indonesia. Bahkan tidak menutup kemungkinan ada lebih dari satu televisi dalam tiap rumah, dalam beberapa kasus tiap ruang yang ada dalam rumah pun memiliki pesawat televisi sendiri.

Televisi berbeda dengan media massa lainnya, terpaan isi siaran yang diluncurkan oleh televisi mampu mempengaruhi cara berpikir dan aktifitas manusia yang menerima terpaannya khususnya anak-anak dan remaja (Dani Fadillah. Uji Publik KPI. Bernas Jogja. 25 Januari 2015).

Hal tersebut karena televisi memang merupakan media utama yang banyak dikonsumsi oleh orang-orang. Saat mereka telah lelah dengan aktivitas pekerjaannya di siang hari, maka salah satu cara untuk mendapatkan hiburan gratis adalah dengan menonton televisi. Terlebih bagi masyarakat dengan ekonomi menengah ke bawah dengan tingkat pendapatan yang terbatas, menonton televisi sebagai hiburan gratis tentu menjadi alternatif, dibandingkan dengan memilih hiburan lain yang perlu mengeluarkan uang, seperti: menonton film di bioskop, 
menonton konser, maupun sekedar mencari makan bersama di luar rumah.

Itu mengapa televisi memang masih menjadi media utama yang banyak dikonsumsi oleh orang-orang di tengah kehadiran media baru, yang bagi sebagian orang belum terlalu familiar dengan media baru ini. Hal yang perlu diwaspadai sekarang ini, adalah bagaimana memilih tayangantayangan televisi yang layak untuk ditonton baik oleh orang dewasa sendiri, maupun anak-anak, serta remaja. Mengingat sekarang ini, acara-acara televisi lebih menonjolkan unsur hiburan yang kurang mendidik. Seolah tidak peduli dengan hal tersebut, masyarakat sendiri justru menikmati euforia acara tersebut. Acara-acara hiburan yang kurang mendidik, justru mempunyai rating dan share yang sangat tinggi dibandingkan dengan acara-acara berita dan lainnya.

Pemahaman untuk memilih acara-acara televisi yang berkualitas menjadi hal yang perlu ditanamkan oleh para orang tua. Orang tua diharapkan mampu mendampingi putra/ putrinya dalam memilih tayangan yang layak untuk ditonton. Pemahaman melek media ini disebut dengan Literasi media. Literasi media adalah upaya untuk peka terhadap isi tayangan media, serta mampu membentengi diri dari pengaruh tayangan negatif media.

Dalam sebuah keluarga peran seorang ibu menjadi penting terkait dengan pendidikan media sejak dini bagi anak-anak. Media terutama televisi merupakan media yang digemari anak-anak karena variasi tayangan mulai dari kartun, sinetron, dan sebagainya. Yang perlu disadari adalah tidak semua tayangan televisi sesuai dengan anakanak. Disinilah muncul tuntutan bahwa ibu harus melek media sehingga mampu menyaring tayangan yang baik atau buruk untuk anak-anak.

Aisyiyah sebagai organisasi otonom Muhammadiyah yang fokus pada pemberdayaan perempuan, tentu tidak boleh lepas dari kemampuan literasi media. Karena dengan memiliki kemampuan literasi tersebut maka tujuan dasar dari Aisyiyah dapat dilaksanakan dengan baik. Perempuan sebagai ibu atau calon ibu nantinya akan berperan penuh dalam memberikan pendidikan dan pengarahan kepada anakanak mereka. Oleh karena itu lah penelitian ini dilakukan untuk mengetahui sejauh mana pemahaman para pengurus Pimpinan Wilayah Aisyiyah Daerah Istimewa Yogyakarta (PWA DIY) periode 2015-2020 terhadap literasi media.

\section{Manusia dan Media}

Dalam Uses and gratification theory menjelaskan terkait apa yang dilakukan oleh manusia pada media, yaitu bagaimana manusia menggunakan media untuk memuaskan kebutuhannya. Penganut teori ini meyakini bahwa individu sebagai mahluk supra-rasional dan sangat selektif. Sebagaimana yang pernah disebutkan oleh Elihu Katz;Jay G. Blumler; dan Michael Gurevitch (dalam Jalaluddin Rakhmat, 2007), uses and gratifications merupakan bagaimana harapan seseorang dalam memenuhi kebutuhan terhadap media massa, yang membawa pada pola terpaan media yang berlainan (atau keterlibatan pada kegiatan lain), dan menimbulkan pemenuhan kebutuhan dan akibat-akibat lain.

Kebutuhan manusia akan media massa tentunya memiliki motif yang berbeda-beda. Dengan kata lain, setiap orang memiliki latar belakang, pengalaman dan lingkungan yang berbeda. Perbedaan ini, tentunya berpengaruh pula kepada pemilihan konsumsi akan sebuah media. Khalayak dianggap aktif, dimana penggunaan media massa diasumsikan memiliki tujuan. Point kedua adalah, dalam proses komunikasi massa banyak inisiatif yang mengaitkan pemuasan kebutuhan dengan pemilihan media terletak pada anggota khalayak. Point ketiga, media massa harus bersaing dengan sumber-sumber lain untuk memuaskan kebutuhannya. Dimana kebutuhannya adalah untuk memuaskan kebutuhan manusia, hal ini bergantung kepada khalayak yang bersangkutan. Point keempat, banyak tujuan pemilih media massa disimpulkan dari data yang diberikan anggota khalayak. 
Point kelima adalah nilai pertimbangan seputar keperluan audience tentang media secara spesifik.

\section{Media dan Perilaku Manusia}

Permulaan proses belajar adalah munculnya peristiwa yang dapat diamati secara langsung atau tidak langsung oleh seseorang. Menurut Hafied Cangara, (2000:87). mengatakan, "hal ini berarti bahwa perilaku baru terjadi apabila ada sesuatu yang diperlukan untuk menimbulkan reaksi, yakni disebut rangsangan. Dengan demikian maka suatu rangsangan tertentu akan menghasilkan reaksi atau perilaku tertentu. Menurut Bandura, bukan saja dari pengalaman langsung, tetapi dari peniruan atau peneladanan (modeling) (Rakhmat, 2002:172). Perilaku merupakan faktor-faktor kognitif dan lingkungan. Peristiwa ini dapat berupa tindakan tertentu atau gambaran pola pemikiran, yang disebut sebagai abstract modeling. Teori ini juga mengakui bahwa manusia mampu menyadari atau berpikir dan bahwa mereka dapat mengambil manfaat dari pengamatan dan pengalaman. Selanjutnya dikatakan bahwa banyak pembelajaran manusia terjadi dengan menyaksikan orang lain yang menampilkan perilaku yang beraneka ragam. Misalnya seorang anak akan belajar banyak dari tayangan televisi yang ditontonnya, misalnya adegan berkelahian dan lain sebagainya.

Jenis pembelajaran ini juga dapat dengan jelas terjadi melalui media massa, menurut Tan (1985:251), media massa memainkan peran yang penting sebab manusia memiliki keterbatasan untuk mengalami peristiwa secara langsung. Banyak dari apa yang dipelajarinya diamati melalui media massa, terutama media visual. Media massa dapat memperluas cakupan apayang dapat individu pelajari dengan menerpanya untuk meniru peristiwa di mana dia tidak memiliki kontak langsung dengan peristiwa itu. Selanjutnya, dikatakan oleh Bandura, proses belajar sosial dibagi dalam empat tahapan proses: proses perhatian, proses pengingatan (retention), proses reproduksi motoris, dan proses motivasional. Tan (1985:252) mengatakan, peristiwa ini dapat berupa tindakan tertentu atau gambaran pola pemikiran, yang disebut Bandura sebagai abstract modeling. Seseorang mengamati peristiwa tersebut dari orang-orang yang berada di sekelilingnya atau sajian televisi.

Dengan menonton televisi, audience dapat melihat gambar yang lebih jelas dari pada media massa lainnya. Daya tarik ini selain melebihi radio juga melebihi film bioskop, karena dengan menonton televisi, program acara dapat dinikmati di rumah dengan aman dan nyaman (Effendy, 2013:68)

Bila peristiwa itu sudah diamati, terjadilah tahap pertama belajar sosial yakni perhatian. Seseorang baru dapat mempelajari sesuatu bila dia memperhatikannya. Perhatian pada suatu peristiwa, dalam perspektif teori ini, ditentukan oleh karakteristik peristiwa (modeling stlimuli), dan karakteristik yang mengamatinya. Kesempatan untuk be-lajar dari satu peristiwa menjadi lebih luas disebabkan oleh pengamatan terhadap peristiwa itu yang berulangulang. Dijelaskan oleh Bandura, seorang anak yang jarang sekali menonton televisi, tak mungkin belajar perilaku agresif yang dilihatnya di televisi. Karakteristik yang ada pada diri pengamat juga memengaruhi perhatian. Kapasitas seseorang untuk memperoleh informasi, menentukan sebaik apa dia akan dapat belajar dari peristiwa yang diamati. Pada proses pengingatan (retention) berhubungan dengan kesanggupan khalayak menyimpan hasil pengamatannya dalam benaknya dan memanggilnya kembali tatkala mereka bertindak sesuai dengan teladan yang diberikan. Peneladanan tertangguh (delayed modeling) hanya terjadi bila mereka sanggup mengingat peristiwa yang diamatinya.

Seorang remaja akan mampu mencontoh gaya hidup remaja di tayangan sinetron, bila dia dapat mengingat contoh yang dilakukan oleh model tersebut. Dalam proses reproduksi motoris untuk mengingat, peristiwa yang diamati harus direkam dalam bentuk imaginal dan verbal. Bentuk imaginal disebut juga visual imagery, berarti membuat gambaran mental tentang peristiwa yang 
diamati dan menyimpan gambaran itu pada memori seseorang. Sedangkan bentuk verbal menunjukkan representasi peristiwa dalam bentuk bahasa.

Menurut Bandura, agar peristiwa dapat diteladani, seseorang bukan saja harus merekamnya dalam bentuk memori, tetapi juga harus mampu membayangkannya secara mental bagaimana seseorang dapat menjalankan tindakan yang diteladaninya. Memvisualisasikan dirinya sedang melakukan sesuatu disebut sebagai rehearsial. Jarang sekali perilaku dapat direproduksihanyadalamsekalipengamatan. Perilaku yang benar merupakan hasil uji coba. Dalam hal ini feedback memiliki peran untuk mengoreksi ketidaksesuaian perilaku hasil pengamatan dan perilaku model. Pada proses motivasional berkaitan dengan kemungkinan menampilkan kembali perilaku yang telah diamati selain bergantung kepada kesempatan dan proses reproduksi motoris, bergantung juga kepada proses motivasional.

Motif bergantung pula pada peneguhan (reinforcement). Menurut teori ini, ada tiga jenis peneguhan yang mendorong seseorang untuk bertindak ketiga peneguhan itu adalah peneguhan eksternal (external reinforcement), peneguhan wakilan (vicarious reinforcement), dan peneguhan diri (self reinforcement). Pengaruh komunikasi massa terhadap khalayak terdiri dari tiga macam, pengaruh pertama, komunikasi massa akan memengaruhi kognisi khalayak yang berupa pengetahuan; kemudian pengaruh kedua adalah afeksi yang meliputi perasaan seseorang mengenai sesuatu; pengaruh ketiga adalah konasi yang meliputi kecenderungan atau keinginan bertindak dari seorang individu mengenai sesuatu (Rinawati, 2002:7).

\section{Sikap Pengambilan Keputusan Menonton Televisi}

Setiap industri media, tentulah berlomba-lomba menampilkan acara televisi yang mampu menarik perhatian. Rating dan share menjadi prioritas indusri media untuk menampilkan suatu tayangan televisi. Tidak heran mengapa, sekarang ini justru indusrti media menampilkan acara-acara yang bersifat entertainer, dengan tidak mengindahkan nilai-nilai edukatif.

Setiap orang tentu mempunyai motivasi yang berbeda-beda dalam menonton tayangan televisi, seperti: tingkat pendidikan, tingkat penghasilan, lifestyle, agama, maupun budaya. Orang yang tingkat pendidikannya tinggi, tentulah akan memiih tayangan-tayangan yang berkualitas, mampu menciptakan adanya ruang publik (public sphere).

Pada dasarnya sebuah keputusan merupakan suatu penentuan sikap terhadap dua pilihan alternatif ataupun lebil (Schiffman dan Kanuk, 2007:228), proses pengambilan keputusan tersebut kemudian dapat dibedakan untuk memilih untuk pertama kalinya atau mencoba (trial) dan pengulangan (repeat). Sementara itu Griffin dan Ebert (2006:283) menyatakan :

Buy decision are based on rational motivates, emotional motivates or both. Rational motives involve the logical evaluation of product attributes:, quality and usefulness. Emotinal motivates involve non objective factors and include sociability, imitation of others and aesthetics.

Dari hal di atas, dapat dikatakan bahwa proses pengambilan keputusan didasarkan pada motif rasional, motif emosional atau keduanya. Di dalam motif rasional nantinya akan melibatkan penilaian logis atas kualitas, kegunaan serta atribut produk.

Dari sana dapat diambil benang merah, bahwa dalam memiih sebuah tayangan televisi didasarkan pada kualitas, motivasi rasional, maupun emosional. Akan tetapi, realitanya sekarang ini tayangan televisi kurang memperhatikan sisi kualitas dan lebih mengedepankan sisi kuantitasnya. Hal ini dapat dicontohkan pada acara-acara di jam-jam prime time tayangan televisi, yakni variety show maupun sinetron. Sinetron sebagai tayangan yang mendapatkan rating tinggi dengan konsep kejar tayang (tayang 
setiap hari), acap kali abai dengan masalah kualitas tayangan, baik dari sisi adegan yang ditampilkan, maupun editingnya.

\section{Regulasi Media Massa}

Tujuan adanya regulasi media adalah memelihara interkomunikasi yang bebas dan luas di dalam masyarakat, dan untuk meningkatkan kualitas produlk, dan menjaga dari keburukan potensial yang mengesahkan kepentingan publik dan pribadi. Regulasi media menurut McQuail (20o8), merupakan sebuah kerangka hukum dan merujuk pada kebijakan publik, hukum, serta peraturan yang mengatur strukur, dan operasionalisasi media.

Regulasi bukan merupakan proses yang sederhana dan memerlukan adanya keterlibatan dari banyak publik dalam perencanannya. Di dalam pelaksanaannya juga adanya upaya untuk pemberian sanksi kepada yang melanggar ketentuan. Media massa merupakan alat yang mempunyai kekuasaan tak terbatas memiliki peluang untuk jatuh pada mereka yang memilikli kepentingan tertentui seandainya dia tidak memiliki batasan yang jelas.

Batasan yang jelas merupakan sebuah strategi untuk memberikan perlindungan dari bahaya kemajuan ICT, kepentingan, serta manipulasi yang memiliki potensi untuk terjadi. Hal utama dalam regulasi media massa adalah mengacu pada mekanisme institusi. Mekanisme institusi mengacu pada mekanisme yang dijalankan media untuk menciptakan tujuan yang ingin dicapai, atau kegiatan media. (Fredman, 2008).

Televisi merupakan sebuah media penyiaran dengan ciri utama dalm hal regilasi ini. Hal tersebut, didasarkan pada masalah peraturan, lisensi, kontrol oleh para penguasa yang pada mulanya berasal dari kebutuhan teknis, pilihan demokrasi yang bebas (Mc Quail, 2011). Sifat dari regulasi media massa merupakan sebuah kontrol yang membatasi segala macam tindaktanduk dan perilaku media massa. Dengan adanya regulasi media massa ini, nantinya dapat memberikan batasan bagaimana sebuah institusi media menciptakan sebuah tayangan, menjalankan kegiatan bisnisnya, serta bagaimana seharusnya media berperan untuk menciptakan kepentingan bersama.

Ada dua jenis regulasi media yang ada, yaitu: state regulation dan self regulation. State regulation adalah regulasi yang diciptakan oleh pemerintah yang nantinya dapat dipatuhi oleh masyarakat dengan maksud untuk mengikat, mengatur dan menjamin hak dan kewajiban warga negara. Sedangkan self regulation merupakan regulasi diri (khalayak) dalam membentengi dan memilih tayangan-tayangan media penyiaran yang sesuai dengan kebutuhannya.

\section{METODE}

Penelitian ini menggunakan Metode Survei Penjelasan (Explanatory Survey Method) yaitu suatu penelitian penjelasan terhadap peristiwa atau keadaan (explanation). Penjelasan ini erat kaitannya dengan pertanyaan apa penyebab atau apa yang memengaruhi terjadinya suatu peristiwa atau keadaan dan akibat yang ditimbulkannya (Kriyantono, 2010:93).

Jenis penelitian ini menggunakan Kuantitatif. Penelitian kuantitatif merupakan suatu prosedur penelitian yang menghasilkan data- data berupa numerik, sampel dari orang-orang atau prilaku yang diamati yang menunjukan berbagai fakta yang ada dan dilihat selama penelitian berlangsung.

\section{Definisi Operasional Variabel Penelitian}

Definisi operasional variabel adalah semacam petunjuk pelaksanaan bagaimana caranya mengukur suatu variabel (Singarimbun dan Efendi, 2003). Penelitian ini menggunakan variabel bebas (X) adalah pemahaman literasi media. Variabel terikat (Y) adalah sikap PWA DIY dalam memilih tanyangan. Definisi operasional dari masingmasing variabel yang digunakan dalam penelitian ini adalah:

\section{a. Variabel Bebas $(\mathrm{X})$}

1) Pemahaman Menonton (X) 
Intensitas menonton adalah kegiatan mendengarkan, melihat, dan membaca pesan media massa atapun mempunyai pengalaman dan perhatian terhadap pesan tersebut, yang dapat terjadi pada tingkat individu ataupun kelompok.

\section{b. Variabel Tergantung $(\mathrm{Y})$}

Variabel tergantung adalah gejala atau unsur variabel yang dipengaruhi variabel lain. Variabel tergantung dari penelitian ini adalah sikap remaja.

* Sikap Pengurus PWA DIY (Y)

Sikap pengurus PWA DIY adalah reaksi atau respon yang masih tertutup dari para pengurus PWA DIY dari isi siaran televisi, dengan indikator:
a) Durasi Menonton
b) Frekuensi Menonton
c) Pemilihan Tayangan

\section{Definisi Pengertian}

Berikut ini adalah definisi dari konsepkonsep yang ada di dalam penelitian ini:

a. Literasi Media

Merupakan pemahaman seseorang dalam memilih tayangan-tayangan media (televisi) yang layak untuk ditonton. Literasi media di sini, berarti dapat memilih media (televisi) yang layak ditonton, kesadaran untuk mengimplementasikan literasi media di keluarga, dan cara yang digunakan untuk mengimplementasikan literasi media tersebut.

b. Pimpinan Wilayah Aisyiyah DIY

Aisyiyah merupakan organisasi otonom Muhammadiyah untuk para Ibu-Ibu. Adapun organisasi Aisyiyah di tingkat provinsi, disebut dengan Pimpinan Wilayah. Wilayah di dalam penelitian ini sendiri adalah Daerah
Istimewa Yogyakarta.

c. Sikap Pimpinan Wilayah Aisyiyah DIY dalam memilih acara televisi yakni terkait bagaimana sikap mereka terhadap tayangan-tayangan televisi yang ada, baik yang positif, dan negatif. Serta bagaimana menyikapi tayangan-tayangan tersebut kepada anak-anak mereka.

\section{Hipotesis}

Dari kerangka pemikiran tersebut, peneliti mencoba membuat hipotesis sebagai berikut:

a. Pengurus PWA DIY mempunyai pemahaman yang baik dalam literasi media (televisi)

b. Pengurus PWA DIY memiliki peran untuk memilihkan acara televisi pada anak-anaknya.

\section{HASIL DAN PEMBAHASAN}

\section{Pemahaman Literasi Media}

a. Pengetahuan tentang simbol aturan tayangan televisi

1) Tingkat perhatian pengurus PWA 'Aisyiyah terhadap tanda program

\section{Memperhatikan simbol program TV}

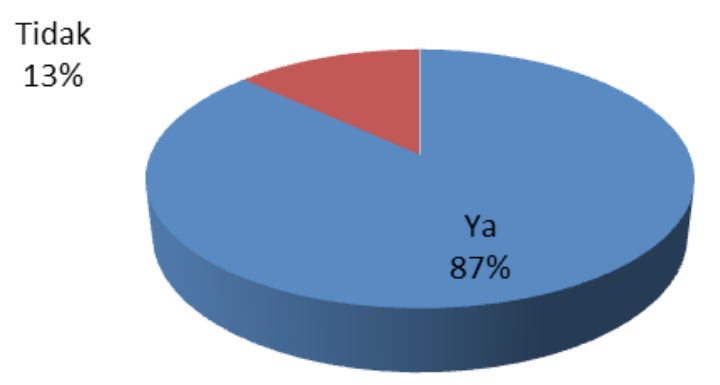

Pertanyaan pertama yang peneliti berikan terkait dengan pemahaman literasi media Pengurus PWA 'Aisyiyah DIY adalah mengenai tingkat perhatikan terhadap simbol program televisi. Dari diagaram di atas, dapat diketahui bahwa $87 \%$ responden memperhatikan simbol yang ada di dalam 
tayangan program televisi, sedangkan 13\% lainnya tidak memperhatikan.

Hal ini berarti mayoritas Pengurus PWA 'Aisyiyah DIY sudah menaruh perhatian terhadap simbol-simbol yang ada di dalam tayangan program televisi. Simbol-simbol tersebut, diantaranya adalah: SU (Semua Umur), BO (Bimbingan Orang Tua), dan R13+ (Remaja di Atas 13 tahun). Dengan demikian dapat diartikan juga bahwa para Pengurus PWA 'Aisyiyah DIY nantinya bisa memilih tayangan-tayangan yang sesuai dengan usia anak-anak mereka.
2) Pemahaman Mengenai Tanda $\mathrm{R}-\mathrm{BO}$

\section{Pemahaman mengenai tanda R-BO}



Pertanyaan kedua yang peneliti berikan terkait dengan pemahaman lierasi media Pengurus PWA 'Aisyiyah DIY adalah mengenai pemahaman mereka terkait dengan tanda R-BO. Dari diagaram di atas, dapat diketahui bahwa $88 \%$ responden mempunyai pemahaman yang baik, sementara $12 \%$ lainnya kurang memiliki pemahaman terhadap tanda tersebut.

Dari hal tesebut, kemudian peneliti juga sempat menanyakan kepada responden mengenai makna simbol tersebut, dan apa yang seharusnya dilakukan apabila melihat adanya simbol tersebut. Responden yang sudah memiliki pemahaman yang baik, ternyata memiliki inisiatif untuk mendampingi anak mereka dalam menyaksikan acara yang memiliki simbol R-BO.
Di antara acara-acara televisi dengan segmentasi anak, yang biasanya juga mencantumkan logo R-BO adalah kartun dan drama seri. Kartun dan drama seri tersebut, umumnya bersifat action, dan menampilkan adegan perkelahian, seperti tayangan kartu naruto, maupun drama seri anak langit. Peran orang tua diperlukan dalam memberikan pendampingan pada program-program tesebut, sebab anak tentu belum bisa menyaring tayangan yang benar dan yang fiktif, sehingga apabila anak menirukan tayangan yang ditampilkam tentu akan sangat berbahaya.

3) Pemahaman Mengenai Tanda
R-BO

\section{Pemahaman mengenai tanda SU}

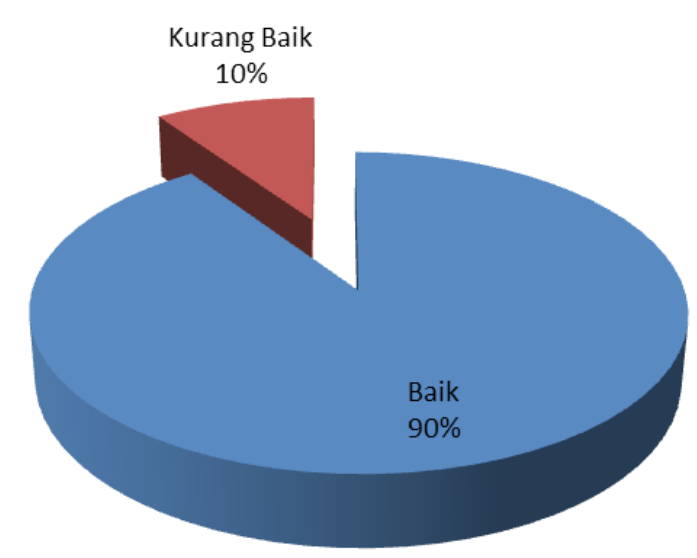

Pertanyaan ketiga yang peneliti berikan terkait dengan pemahaman literasi media Pengurus PWA 'Aisyiyah DIY adalah mengenai pemahaman mereka terkait dengan tanda SU. Dari diagram di atas, dapat diketahui bahwa 92\% responden mempunyai pemahamanyang baik, sementara $8 \%$ lainnya kurang memiliki pemahaman terhadap tanda tersebut.

Tayangan dengan simbol SU artinya dapat ditonton oleh semua umur, sehingga para orang tua maupun Pengurus PWA 'Aisyiyah tidak perlu khawatir dengan acara-acara yang mempunyai simbol SU. Hanya saja orang tua harus memberikan batasan kepada anak, terkait dengan durasi menonton televisi dan waktu yang tepat untuk menonton televisi, jangan sampai 
anak menjadi malas belajar dan cenderung menghabiskan waktunya untuk menonton televisi.

4) Pemahaman Mengenai Tanda R13

\section{Pemahaman mengenai tanda R-13+}

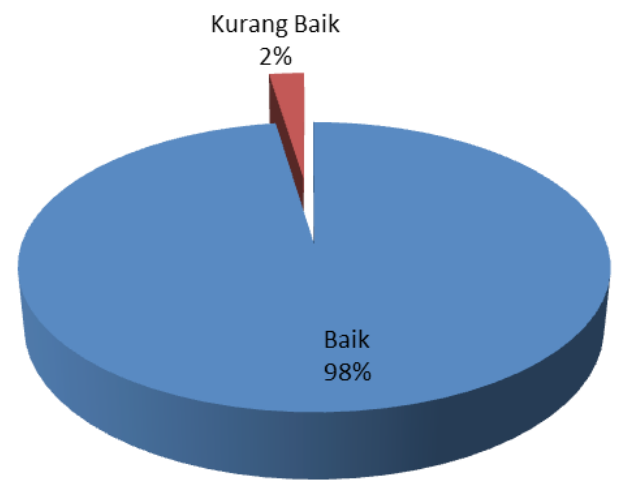

Pertanyaan selanjutnya yang peneliti berikan terkait dengan pemahaman literasi media Pengurus PWA 'Aisyiyah DIY adalah mengenai pemahaman mereka terkait dengan tanda R13+. Dari diagram di atas, dapat diketahui bahwa $98 \%$ responden mempunyai pemahaman yang baik, sementara $2 \%$ lainnya kurang memiliki pemahaman terhadap tanda tersebut.

Tayangan dengan simbol R13+ artinya tayangan tersebut adalah tayangan yang hanya boleh ditonton oleh remaja berusia di atas 13 tahun. Tayangan-tayangan tersebut pada umumnya, menampilkan adegan kekerasan, percintaan, dan lain sebagainya yang tidak layak untuk ditonton oleh anakanak di bawah umur.

Para Pengurus PWA 'Aisyiyah DIY diharusnya untuk bisa tegas untuk tidak memberikan izin kepada anak-anak yang masih di bawah umur untuk tidak menyaksikan acara dengan simbol seperti ini. Ataupun jika terpaksa harus menonton tayangan dengan tanda seperti ini, para orang tua hendaknya dapat memberikan pendampingan ekstra kepada anak-anak mereka.

b. Pengetahuan terhadap program tayangan televisi

1) Pemahaman terhadap program televisi yang positif

\section{Pemahaman mengenai program TV yang positif}

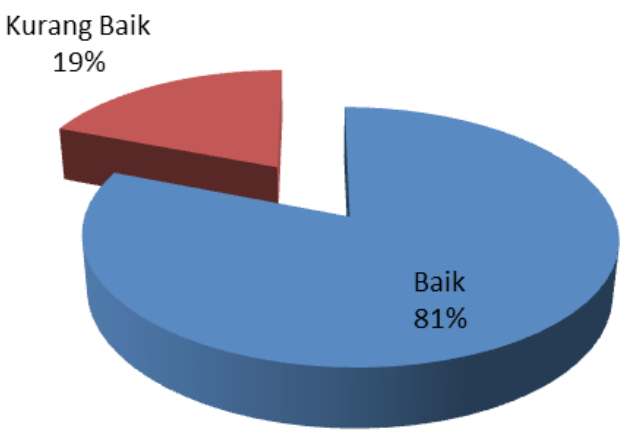

Pertanyaan selanjutnya yang peneliti berikan terkait dengan pemahaman literasi media Pengurus PWA 'Aisyiyah DIY adalah mengenai pemahaman mereka terkait program-program televisi yang positif. Dari diagram di atas, dapat diketahui bahwa $81 \%$ responden mempunyai pemahaman yang baik mengenai program tv yang positif, dan 19\% lainnya kurang memiliki pemahaman mengenai program televisi yang positif.

Dari hal tesebut, artinya para Pengurus PWA 'Aisyiyah DIY sudah memiliki pemahaman yang baik terkait programprogram televisi yang positif dan layak ditonton oleh semua anggota keluarga. Adanya pemahaman tersebut yang tinggi tersebut mengindikasikan bahwa para Pengurus PWA 'Aisyiyah DIY telah memiliki pemahaman literasi media yang tinggi, dapat memilih program yang berkualitas, serta dapat memberikan pendampingan kepada anak-anaknya.

2) Pemahaman mengenai program

\section{Pemahaman mengenai program TV yang negatif}

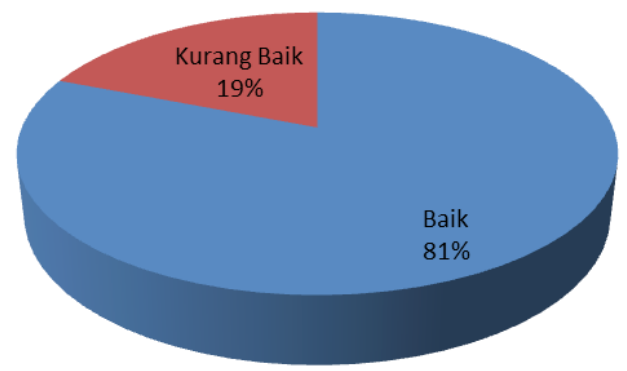


Pertanyaan selanjutnya yang peneliti berikan terkait dengan pemahaman literasi media Pengurus PWA 'Aisyiyah DIY adalah mengenai pemahaman program televisi yang negatif. Dari diagram di atas, dapat diketahui bahwa 81\% responden mempunyai pemahaman yang baik mengenai program tv yang positif, dan 19\% lainnya kurang memiliki pemahaman mengenai program televisi yang positif.

Dari hal tesebut, artinya para Pengurus PWA 'Aisyiyah DIY sudah memiliki pemahaman yang baik terkait programprogram televisi yang negatif dan tidak layak ditonton oleh anak-anak ataupun anggota keluarga. Acara televisi seperti reality show, variety show, maupun gosip selebriti merupakan acara-acara yang masuk dalam kategori negatif. Hal tesebut dikarenakan acara tersebut pada umumnya menampilkan candaan yang kurang sopan, seperti: budaya bully, mencaci, kata-kata kasar, dan memperbincangkan kejelekan orang lain (artis). Sehingga acara-acara seperti ini, sebaiknya dihindari untuk tidak ditonton.

3) Pemahaman mengenai program televisi yang baik bagi anak

\section{Pemahaman mengenai program TV yang Baik bagi anak}

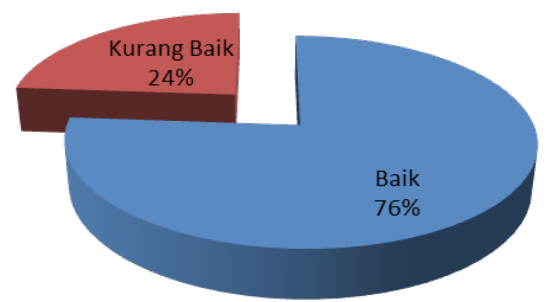

Pertanyaan selanjutnya yang peneliti berikan terkait dengan pemahaman literasi media Pengurus PWA 'Aisyiyah DIY adalah mengenai pemahaman mereka terkait program-program televisi yang baik bagi anak. Dari diagram di atas, dapat diketahui bahwa $76 \%$ responden mempunyai pemahaman yang baik mengenai program televisi yang bagi bagi anak, dan 24\% lainnya kurang memiliki pemahaman yang baik.

Dari hal tesebut, artinya para Pengurus PWA 'Aisyiyah DIY sudah memiliki pemahaman yang terhadap program- program yang layak untuk ditonton oleh anak-anak. Para Pengurus PWA 'Aisyiyah artinya sudah mempunyai mampu menjadi seorang khalayak aktif, yang dapat memilihkan program-program yang layak untuk ditonton. Jika kita hubungkan dengan tingkat pendidikan para responden, mayoritas diantara mereka memang mempunyai pendidikan S1 sehingga para responden nampaknya sudah cukup bijak untuk memilih program televisi yang baik bagi anak-anak mereka.

4) Pemahaman mengenai program televisi yang buruk bagi anak

\section{Pemahaman mengenai program TV yang buruk bagi anak}

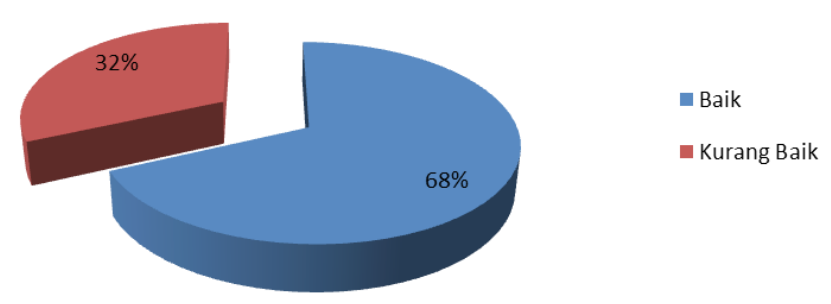

Pertanyaan selanjutnya yang peneliti berikan terkait dengan pemahaman literasi media Pengurus PWA 'Aisyiyah DIY adalah mengenai pemahaman mereka terkait program-programyang buruk bagi anak. Dari diagram di atas, dapat diketahui bahwa 68\%, responden mempunyai pemahaman yang baik mengenai program tv yang positif, dan 32\% lainnya kurang memiliki pemahaman mengenai program televisi yang positif.

Sebagian besar di antara program televisi memang lebih banyak yang negatif (kurang baik ditonton oleh anak-anak). Hal tersebut dikarenakan program-program televisi lebih banyak bersifat hiburan yang bertujuan untuk mendapatkan rating tinggi dari para penontonnya. Anak-anak yang belum bisa memilih tayangan yang baik, tentu membutuhkan peran orang tua dalam menonton tayangan televisi tersebut. Di sinilah orang tua seharusnya, mampu menjembatani kebutuhan anak untuk menonton televisi, memilihkan 
tayangan yang berkualitas, memberikan pendampingan, serta membatasi intensitas menonton anak merupakan hal yang perlu dilakukan oleh setiap orang tua.

c. Faktor usia dalam pemilihan tayangan televisi

\section{Usia subyek penelitian}

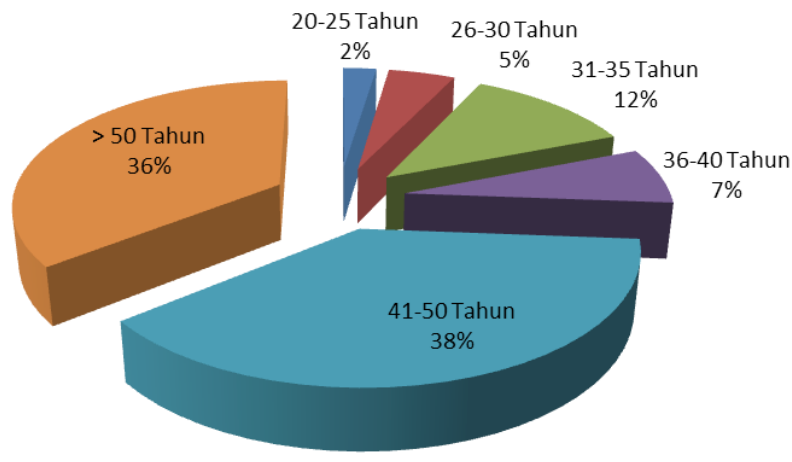

Dari diagram di atas menunjukkan bahwa, usia responden dalam penelitian ini, diantaranya: 41-50 tahun berjumlah 38\%, di atas 50 tahun berjumlah 36\%, 31-35 tahun berjumlah 12\%, 36-40 tahun berjumlah $7 \%$, 26-30 tahun berjumlah 5\%, dan 20-25 tahun berjumlah $2 \%$.

Dari diagram tersebut, menunjukkan bahwa mayoritas responden dalam penelitian ini adalah mereka yang memiliki umur 4150 tahun, artinya merupakan ibu-ibu yang sudah cukup umur untuk membimbing anak-anak mereka dalam memilih tayangantayangan televisi yang layak untuk ditonton oleh anak-anaknya. Orang tua dengan umur itu tentu sudah mempunyai pengalaman yang banyak untuk memberikan arahan kepada anak-anaknya.

d. Tingkat pendidikan dan pemilihan tayangan televisi

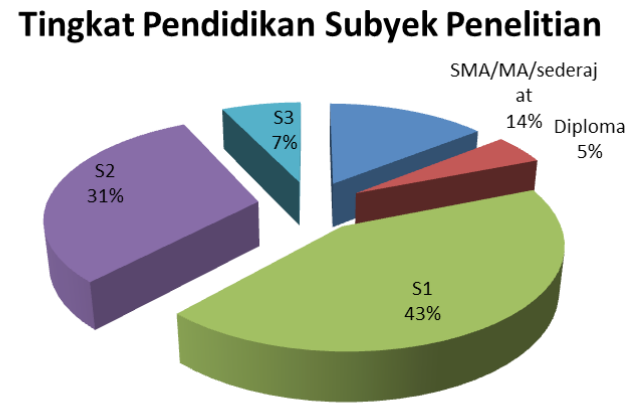

Dari diagram di atas menunjukkan bahwa, tingkat pendidikan dalam penelitian ini, diantaranya: S1 berjumlah 43\%, S2 berjumlah 31\%, SMA/MA berjumlah 14\%, S3 berjumlah 7\%, dan Diploma berjumlah 5\%.

Dari diagram tersebut, menunjukkan bahwa mayoritas responden dalam penelitian ini adalah mereka yang memiliki tingkat pendidikan tinggi. Adayang S1, S2, bahkan S3. Orang-orang yang mempunyai pendidikan tinggi, tentu mempunyai pengetahuan yang baik mengenai literasi media. Yang menjadi catatan di sini, adalah mereka pada umumnya menjadi perempuan yang berkarir yang justru lebih banyak menghabiskan waktu mereka di luar. Oleh karenanya, mereka harus mampu membagi waktu yang baik, antara bekerja dan memberikan perhatian bagi anak-anaknya, terutama dalam kaitannya dengan memilihkan dan memberikan pendampingan kepada anak dalam menonton tayangan televisi.

\section{Sikap PWA Aisyiyah}

a. Sikap kepada anak terkait kegiatan menonton televisi

\section{Tidak boleh Sikap yang ditunjukkan terhadap \\ $2 \%$ program TV bagi anak}

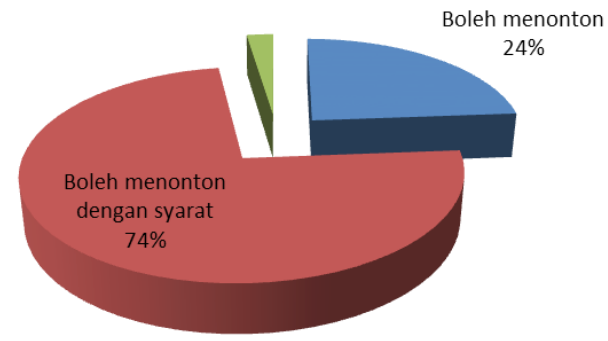


Dari diagram di atas menunjukkan bahwa, sikap yang ditunjukkan oleh Pengurus PWA 'Aisyiyah DIY adalah 74\% memperbolehkan menonton dengan syarat, $24 \%$ boleh menonton, dan $2 \%$ tidak boleh.

Dari diagram tersebut, menunjukkan bahwa mayoritas responden dalam penelitian ini adalah mereka yang memperbolehkan anaknya untuk menonton tayangan televisi, namun dengan syarat. Hal ini nampaknya merupakan indikator pemahaman literasi media yang dimiliki oleh Pengurus PWA 'Aisyiyah DIY. Para Ibu-Ibu tersebut, telah memahami pentingnya putra/putri untuk memperoleh hiburan dari tayangan televisi. Mereka mengizinkan putra/putrinya untuk menonton tayangan televisi, dengan syaratsayarat yang dibuat, misalnya: menonton televisi saat sore hari/malam, menonton televisi saat hari libur. Mereka tentunya juga memilihkan tayangan-tayangan televisi yang layak untuk ditonton oleh putra/putrinya.

b. Pilihan waktu untuk menonton televisi

\section{Pilihan Waktu Menonton TV}

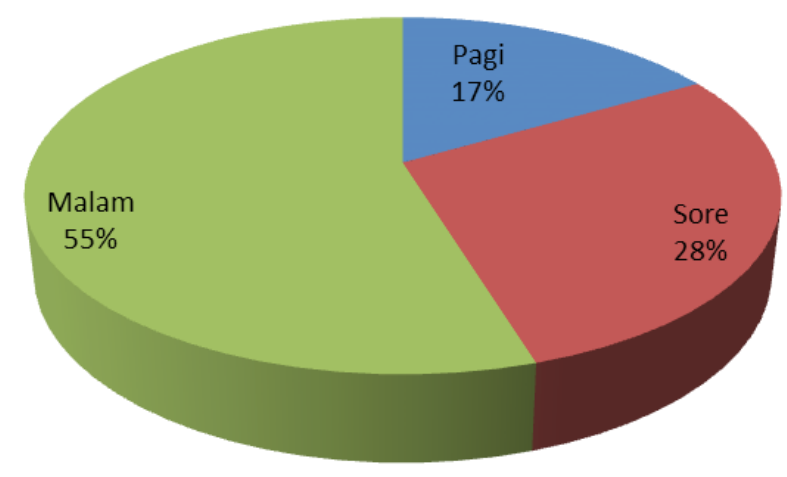

Dari diagram di atas menunjukkan bahwa, pilihan waktu yang digunakan untuk menonton televisi oleh Pengurus PWA 'Aisyiyah DIY adalah 55\% malam hari, 28 sore hari, dan $17 \%$ pagi hari.

Dari diagram tersebut, menunjukkan bahwa mayoritas responden dalam penelitian ini memilih waktu di malam hari untuk menonton tayangan televisi. Hal ini relevan dengan pertanyaan sebelumnya, yakni memperbolehkan menonton televisi, namun dengan syarat. Hal ini berarti menunjukkan salah satu syarat yang diberikan adalah mengenai pemilihan waktu, yakni pada malam hari. Pada malam hari, para orang tua juga relatif lebih luang dibandingkan saat pagi/siang hari yang merupakan waktu bekerja. Sehingga para orang tua bisa memberikan pendampingan bagi putra/ putrinya untuk memilih tayangan televisi yang baik, dan juga menjelaskan apabila ada adegan-adegan tayangan televisi yang mungkin belum dimengerti oleh putra/ putrinya.

c. Durasi menonton televisi bagi anak

\section{Durasi Anak Menonton TV}
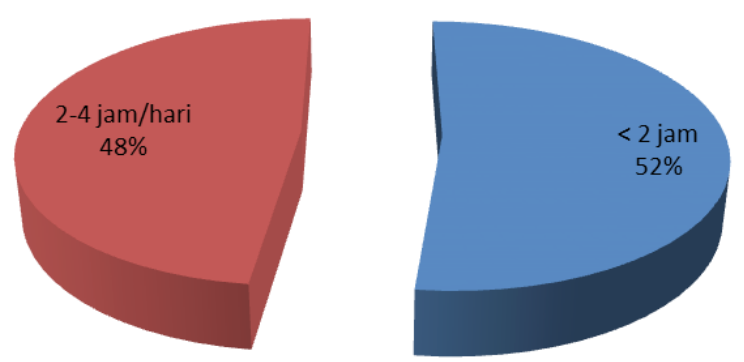

Dari diagram di atas menunjukkan bahwa, durasi yang diberikan anak untuk menonton tayangan televisi adalah kurang dari 2 jam sebesar 52\%, dan 2-4 jam sebesar $48 \%$.

Dari diagram tersebut, menunjukkan bahwa mayoritas responden dalam penelitian ini memperbolehkan putra/putrinya untuk menonton televisi yakni kurang dari 2 jam setiap harinya. Menyadari akan perlunya aktivitas lainyang harusdilakukananak, tentu memperbolehkan anak untuk menonton televisi kurang dari 2 jam adalah pilihan yang bijaksana. Anak-anaknya, perlu untuk belajar di rumah, mengerjakan PR, ataupun aktivitas lainnya. Para orang tua, semestinya harus tegas terhadap aturan-aturan yang telah disepakati dengan putra/putrinya. Terkadang karena kesibukan lain dari orang tuanya, sehingga para orang tua kurang bisa tegas atau tidak bisa mendampingi putra/ putrinya dalam menonton tayangan televisi. Di sinilah, semestinya para orang tua perlu membagi peran. Jika seorang ayah telah sibuk 
dengan pekerjaan dan tugasnya, maka ibulah yang bisa mengambil peran untuk sekedar meluangkan waktu bersama menonton televisi dengan putra/putrinya.

d. Frekuensi menonton televisi bagi anak

\section{Frekuensi anak menonton TV}

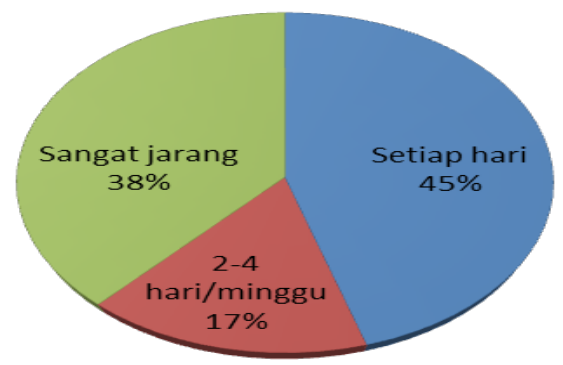

Dari diagram di atas menunjukkan bahwa, frekuensi anak menonton televisi adalah $45 \%$ setiap hari, $38 \%$ sangat jarang menonton televisi, dan 2-4 hari/minggu sebesar $17 \%$.

Dari diagram tersebut, menunjukkan bahwa mayoritas responden dalam penelitian ini adalah menonton televisi setiap harinya yakni sebesar $45 \%$. Hal ini menunjukkan bahwa televisi memang media utama yang ditonton oleh putra/putrinya. Hampir semua anak di pagi hari menghabiskan waktunya dengan sekolah, maka malam hari tentunya menjadi pilihan untuk menonton televisi. Yang perlu diperhatikan di sini, adalah pada malam hari (jam prime time), tayangantayangan televisi lebih banyak bersifat hiburan yang kurang mendidik, seperti halnya: drama seri, maupun variety show.

Drama seri sendiri mayoritas di jamjam tersebut adalah untuk para remaja, yang berceritamengenaikisah percintaan, maupun kenakalan para remaja. Pada umumnya, drama seri ini mempunyai simbol R13+yang artinya hanya boleh ditonton oleh para remaja yang telah berusia 13 tahun ke atas. Peran oran tua, sangat diperlukan di sini, memberikan pendampingan dalam menonton tayangan tersebut, maupun bersikap tegas dengan tidak memperbolehkan putra/putrinya yang belum cukup umur untuk menyaksikan tayangan-tayangan tersebut. e. Sikap terhadap dampak negatif program televisi

\section{Sikap terhadap dampak negatif program \\ TV \\ Tidak Baik \\ $0 \%$}

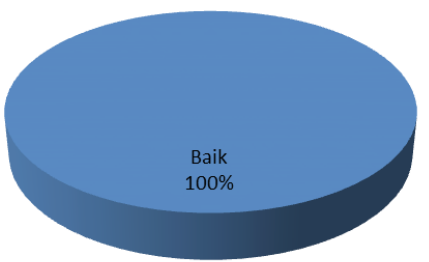

Dari diagram di atas menunjukkan bahwa, 100\% Pengurus PWA 'Aisyiyah DIY telah memahami tentang dampak buruk tayangan televisi, dan mereka juga mempunyai sikap yang tegas untuk putra/ putrinya terhadap tayangan-tayangan yang berpotensi terdahap tindakan-tindakan yang negatif. Dari sini dapat disimpulkan bahwa, memang pemahaman literasi media Pengurus PWA 'Aisyiyah DIY sudah baik, artinya mereka mampu memberikan batasan-batasan terhadap pemilihan tayangan-tayangan televisi yang ditonton oleh putra/putrinya, membatasi durasi menonton, mendampingi putra/putrinya dalam menonton televisi, dan bersikap tegas dengan memberikan larangan agar putra/ putrinya tidak menonton tayangan televisi yang kurang sesuai.

\section{Pengaruh Pemahaman Literasi Media terhadap sikap terhadap anak}

Coefficients $^{\mathrm{a}}$

\begin{tabular}{|c|c|c|c|c|c|}
\hline \multirow[t]{2}{*}{ Model } & \multicolumn{2}{|c|}{$\begin{array}{c}\text { Unstandardized } \\
\text { Coefficients }\end{array}$} & \multirow{2}{*}{\begin{tabular}{|c|}
$\begin{array}{l}\text { Standardized } \\
\text { Coefficients }\end{array}$ \\
Beta
\end{tabular}} & \multirow[b]{2}{*}{$\mathrm{t}$} & \multirow[b]{2}{*}{ Sig. } \\
\hline & $\mathrm{B}$ & Std. Error & & & \\
\hline 1 (Constant) & 9.233 & .890 & & 10.377 & .000 \\
\hline pemahaman & -.201 & .103 & -.294 & -1.947 & .059 \\
\hline
\end{tabular}

a. Dependent Variable: sikap

Analisis data menggunakan regresi linier sederhana untuk mengetahui pengaruh pemahaman literasi media terhadap sikap orang tua dalam mengontrol aktivitas menonton TV. Berdasarkan hasil analisis diperoleh hasil yang menunjukkan bahwa $\mathrm{p}=0.059(\mathrm{p}>0.05)$. Dengan demikian, dapat 
disimpulkan bahwa pemahaman literasi media tidak memiliki pengaruh yang signifikan terhadap sikap orang tua dalam mengontrol aktivitas menonton TV.

Dari hal tersebut, ada hal yang menarik untuk dikaji lebih dalam. Yakni tingginya pemahaman literasi media Pengurus PWA 'Aisyiyah DIY ternyata tidak mempengaruhi sikap yang ditunjukkan kepada putra/ putrinya. Jika melihat dari definisi literasi media sendiri yakni peka terhadap media, mampu membentengi diri dari pengaruh buruk media. Dari sana dapat ditarik benang merah, bahwa indikasi orang yang punya pemahaman literasi media yang baik, juga mampu memilih tayangan-tayangan media yang layak untuk ditonton. Orang tersebut, akan mampu memberikan edukasi kepada orang-orang di sekitarnya, tentang pengaruh buruk dari media televisi itu sendiri.

Jika dilihat dari mayoritas jawaban para Pengurus 'Aisyiyah DIY, mereka telah mampu menyebutkan nama-nama program acara yang baik, dan yang buruk, serta dampak positif, dan dampak negatif dari tayangan televisi. Artinya di sini, memang para Pengurus PWA 'Asiyiyah telah mempunyai pemahaman literasi mediayang tinggi. Hanya saja hal tersebut ternyata tidak berpengaruh terhadap sikap mereka kepada putraputrinya. Misalnya tercermin dari durasi yang diperbolehkan menonton tayangan televisi, yakni sebesar 52\% memberikan waktu sampai 2 jam untuk menonton televisi. Selain itu para Pengurus PWA 'Aisyiyah DIY juga memberikan frekuensi setiap hari pada waktu malam kepada para putra/putrinya untuk menonton televisi.

Sikap-sikap tersebut sebenarnya merupakan hal yang wajar dilakukan oleh orang tua kepada anaknya. Orang tua tentunya juga tidak ingin mengekang putra/putrinya untuk terus-mnerus belajar. Padatnya aktivitas di sekolah, tentu perlu diimbangi dengan nilai-nilai hiburan. Televisi memungkinkan hal ini. Di mana televisi menawarkan berbagai macam tayangan hiburan yang dapat digunakan untuk berkumpul dengan para anggota keluarga lainnya.
Membatasi putra/putri dalam menonton tayangan televisi perlu dilakukan oleh para Pengurus PWA 'Aisyiyah. Saat harihari biasa, setidaknya anak diberikan waktu maksimal untuk menonton tayangan televisi adalah sampai pukul 20.0o. Kedisiplinan perlu ditanamkan oleh para orang tua, lewat pukul 20.0o seharusnya putra/putrinya sudah tidak diperbolehkan untuk menonton tayangan televisi. Anak-anak tentunya juga perlu mengerjakan PR dari sekolah, maupun belajar, dan tidur tidak terlalu malam. Sehingga pagi harinya, mereka bisa berangkat ke sekolah dengan tepat waktu. Terkecuali pada hari-hari libur, anak bisa saja diperbolehkan untuk menonton lebih dari pulul 20.00, mungkin sampai pukul 21.0o bahkan 22.00. Konsekuensi dari diperbolehkannya anak untuk menonton televisi sampai larut malam, tentu orang tua harus tetap mendampingi mereka. Mengingat acara-acara televisi di tengah malam, rata-rata banyak yang menyuguhkan tayangan-tayangan untuk usia 17+. Sehingga upaya pendampingan anak dalam menoton televisi, di waktu libur tetap saja perlu dilakukan.

\section{Pengaruh usia dan tingkat pendidikan terhadap tayangan televisi}

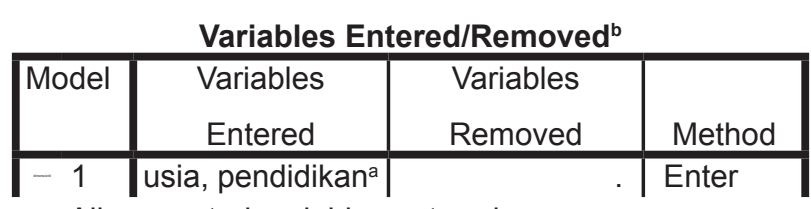

a. All requested variables entered.

b. Dependent Variable: frekuensi

\begin{tabular}{|r|c|r|r|r|}
\hline \multicolumn{5}{|c|}{ Model Summary } \\
\hline & & $\mathrm{R}$ & Adjusted R & Std. Error of \\
& $\mathrm{R}$ & Square & Square & the Estimate \\
\hline-1 & $.126^{\mathrm{a}}$ & .016 & -.035 & .9369 \\
\hline
\end{tabular}

a. Predictors: (Constant), usia, pendidikan 
ANOVA $^{b}$

\begin{tabular}{|c|c|c|c|c|c|}
\hline Model & $\begin{array}{l}\text { Sum of } \\
\text { Squares }\end{array}$ & df & $\begin{array}{c}\text { Mean } \\
\text { Square }\end{array}$ & $F$ & Sig. \\
\hline 1 Regression & .553 & 2 & .277 & .315 & $.732^{\mathrm{a}}$ \\
\hline Residual & 34.232 & 39 & .878 & & \\
\hline Total & 34.786 & 41 & & & \\
\hline
\end{tabular}

a. Predictors: (Constant), usia, pendidikan

b. Dependent Variable: frekuensi

\section{Coefficients $^{\mathrm{a}}$}

\begin{tabular}{|c|c|c|c|c|c|}
\hline \multirow[t]{2}{*}{ Model } & \multicolumn{2}{|c|}{$\begin{array}{c}\text { Unstandardized } \\
\text { Coefficients }\end{array}$} & $\begin{array}{c}\text { Standardized } \\
\text { Coefficients }\end{array}$ & & \\
\hline & B & $\begin{array}{l}\text { Std. } \\
\text { Error }\end{array}$ & Beta & $t$ & Sig. \\
\hline 1 (Constant) & 2.469 & .701 & & 3.522 & .001 \\
\hline pendidikan & -.052 & .132 & -.062 & -.390 & .698 \\
\hline usia & -.078 & .113 & -.109 & -.687 & .496 \\
\hline
\end{tabular}

a. Dependent Variable: frekuensi

Berdasarkan hasil analisis di atas, diketahui bahwa:

1. Pendidikan tidak memiliki pengaruh yang signifikan terhadap frekuensi menonton TV ( $\mathrm{p}=0.698$, $\mathrm{p}>0.05)$.

2. Usia tidak memiliki pengaruh yang signifikan terhadap frekuensi menonton TV $(\mathrm{p}=0.496, \mathrm{p}>0.05)$.

Tidak adanya pengaruh tingkat pendidikan dan usia responden terhadap frekuensi acara televisi tersebut dapat kita ambil benang merah, bawah PWA 'Aisyiyah DIY memang telah memiliki pemahaman yang baik dalam memilih acara televisi yang ada. Mereka juga mempunyai sikap tersendiri dalam memperbolehkan putra/ putrinya dalam menonton acara televisi.

Upaya-upaya untuk meningkatkan pemahaman literasi media Pengurus PWA 'Aisyah DIY perlu tetap dilakukan. Tidak hanya dengan para pengurusnya saja, namun juga kepada para anggotanya. Sehingga nantinya para ibu-ibu 'Aisyiyah bisa lebih mengoptimalkan perannya untuk memberikan pendampingan kepada putraputrinya terhadap pengaruh negatif tayanyan televisi. Beberapa pengaruh negatif tersebut, seperti: anak menjadi malas belajar karena kecanduan televisi, maupun meniru adegan yang tidak pantas dilakukan di usianya.
Beberapa upaya untuk meningkatkan literasi media, seperti: mengadakan pelatihan mengenai literasi media, mengadakan diskusi mengenai dampak buruk dari tayangantayangan televisi, ataupun diskusi mengenai upaya-upaya pencegahan terhadap dampak buruk dari acara televisi.

Tingkat pendidikan para pengurus PWA 'Aisyiyah sendiri yang mayoritas menempuh pendidikan di perguruan tinggi $\left(\mathrm{S}_{1}\right), \mathrm{S}_{2}$, bahkan $\mathrm{S}_{3}$ tentu memberikan dampak yang positif bagi 'Aisyiyah sendiri terutama dalam kaitannya dengan literasi media. Orang yang mempunyai tingkat pendidikan tinggi, tentu mempunyai sikap kritis yang lebih baik daripada orang-orang yang berpendidikan rendah. Mereka dikategorikan sebagai khayalayak aktif, yang bisa menyaring tayangan-tayangan di televisi. Bisa memilih tayangan yang positif, bisa memberikan pemahaman yang baik kepada putra/ putrinya, dan mampu mencegah dampak buruk dari tayangan televisi.

Dari hasil penelitian, para Pengurus PWA 'Aisyiyah juga telah berupaya untuk memberikan pendampingan kepada putra/putrinya saat menonton televisi. Mereka meluangkan waktu untuk sekedar menonton televisi bersama keluarga, tak jarang mereka menjelaskan tayangan yang belum dimengerti oleh anak-anak. Mereka juga memberi batasan kepada anak-anak terkait durasi menonton televisi, frekuensi menonton, dan memberikan batasan terhadap tayangan yang boleh dan tidak boleh untuk ditonton.

\section{SIMPULAN}

Adapun beberapa kesimpulan yang bisa diambil dalam penelitian ini, adalah sebagai berikut. Pengurus PWA 'Aisyiyah DIY telah mempunyai pemahaman literasi media yang baik, seperti: mampu memahami arti dari tanda/symbol yang ada dalam tayangan televisi (SU, BO, R13+, atau 17+), mampu membedakan tayangan yang positif, dan tayangan yang negatif untuk ditonton oleh putra/putrinya.

Para Pengurus PWA 'Aisyiyah DIY 
mempunyai sikap dalam memberikan akses kepada putra/putrinya dalam menonton tayangan televisi. Adapun sikap yang mereka tunjukkan, seperti: membatasi durasi menonton tayangan televisi, membatasi frekuensi menonton televisi, dan memberikan pendampingan bagi anak dalam menonton tayangan televisi.

Tidak ada pengaruh yang signifikan antara pemahaman literasi media Pengurus PWA 'Aisyiyah DIY terhadap sikap mereka kepada putra/putrinya dalam menonton tayangan televisi.

Tingkat pendidikan, dan usia tidak mempengaruhi frekuensi dan durasi dalam menonton televisi. Dalam hal ini dapat dikatakan bahwa tingkat pendidikan, dan usia tidak memberikan pengaruh terhadap sikap yang ditunjukkan para Pengurus PWA 'Aisyiyah DIY dalam memberikan edukasi kepada putra-putrinya dalam menonton tayangan televisi.

Berdasarkan kesimpulan di atas, peneliti dapat memberikan saran sebagai berikut: perlunya peningkatan pemahaman literasi media tidak hanya bagi Para Pengurus PWA 'Aisyiyah DIY, namun juga kepada seluruh anggotanya. Hal ini dimaksudkan untuk meningkatkan peran 'Aisyiyah dalam memberikan edukasi kepada putra-putrinya terhadap pengaruh buruk tayangan televisi.

Para Pengurus PWA 'Aisyiyah DIY, diharapkan bisa bersikap lebih tegas lagi dalam mencegah dampak buruk dari tayangan televisi. Misalnya dengan mengurangi durasi dalam menonton televisi, memberikan larangan tegas kepada putra/ putrinya untuk tidak menonton tayangan televisi yang tidak sesuai dengan umurnya.

\section{DAFTAR PUSTAKA}

Cangara, Hafied. (2000). Pengantar Ilmu komunikasi. Jakarta: Raja Grafindo Persada.

Effendy, Onong Uchjana. (2013). Komunikasi Teori E Praktek Dinamika Komunikasi. Bandung:Alumni.

Ghozali, Imam. (2011). Aplikasi Analisis Multivariate Dengan Program SPSS. Semarang: Badan Penerbit Universitas Diponegoro

Jalaluddin Rakhmat. (2002). Psikologi Komunikasi. Bandung: Remaja Rosdakarya.

Kriyantono, Rachmat. (2010). Teknik Praktis Riset Komunikasi. Jakarta: Kencana

Rakhmat, Jalaluddin. (2007). Metode Penelitian Komunikasi, Bandung: RemadjaKarya

Rinawati, Rini. (2002) "Pengaruh SinetronTerhadap Sikap Ibu-Ibu MengenaiPeran Ganda Wanita”. MediatorJurnalKomunikasi, Volume 3. No. 1, hal.11o.

Singarimbun, dan Effendin (2003). Metode Penelitian Survey. Cetakan Kedua, Penerbit PT. Pustaka LP3ES Indonesia, Jakarta

Sugiyono. 2006. Metode Penelitian Kuantitatif Kualitatif dan REDD. Bandung: Alfabeta

Solomon, Michael, dkk. 2006. Consumer Behaviour-Third Edition. London:Prentice Hall

Tan, Alexis S. (1985). Mass CommunicationTheories and Research. Columbus Ohio: Grid Publishing, inc. 
INFORMASI Kajian Ilmu Komunikasi Volume 47. Nomor 2. Desember 2017 